\title{
Successful repeated uterine artery embolization in postpartum hemorrhage with disseminated intravascular coagulation: a case report and literature review
}

Shunya Sugai ${ }^{*}$ (D), Taro Nonaka ${ }^{1}$, Kana Tamegai ${ }^{1}$, Tatsuhiko Sato ${ }^{2}$, Kazufumi Haino ${ }^{1}$, Takayuki Enomoto ${ }^{1}$ and Koji Nishijima ${ }^{1}$

\begin{abstract}
Background: Postpartum hemorrhage (PPH) is a potentially fatal condition requiring urgent and appropriate intervention. Uterine artery embolization (UAE) has a high hemostatic capacity for PPH, but it may fail. Disseminated intravascular coagulation (DIC) has been reported as a risk factor associated with the failure of UAE.

Case presentation: A 37-year-old primigravida with dichorionic diamniotic twins and placenta previa underwent cesarean section. The blood loss during surgery was $4950 \mathrm{~mL}$. Hemostasis was achieved using an intrauterine balloon tamponade device. However, she lost a further $2400 \mathrm{~mL}$ of blood $5 \mathrm{~h}$ after surgery. We embolized both uterine arteries using gelatin sponges and confirmed hemostasis. She was suffering from DIC and received ample blood transfusions. However, a further $1300 \mathrm{~mL}$ of blood was lost $18 \mathrm{~h}$ after surgery and we performed repeated UAE, with complete recanalization of the uterine arteries on both sides and re-embolization with gelatin sponges. Her DIC was treated successfully by blood transfusions at this time, and she showed no further bleeding after the repeated UAE.
\end{abstract}

Conclusions: DIC is a risk factor for the failure of UAE. Repeated UAE may be effective after sufficient improvement of the hematological status in patients with PPH and DIC.

Keywords: Disseminated intravascular coagulation, Gelatin sponge, N-butyl cyanoacrylate, Postpartum hemorrhage, Uterine artery embolization

\section{Background}

Postpartum hemorrhage (PPH) is a major cause of maternal mortality and morbidity [1]. Causes of PPH include uterine atony, placenta previa, cervical tears, coagulation disorders, and retained parts of the placenta. Successful management of PPH can be achieved by identification of the cause and rapid treatment. PPH is initially managed

\footnotetext{
*Correspondence: sugoi3215@gmail.com

1 Departments of Obstetrics and Gynecology, Niigata University Medical and Dental Hospital, 1-757 Asahimachi-dori, Chuo-ku, 951-8510 Niigata, Japan

Full list of author information is available at the end of the article
}

with less-invasive treatments, including uterotonic agents and tranexamic acid. If uterine bleeding persists despite these interventions, mechanical and surgical interventions should be initiated. An internal balloon tamponade device can provide hemostasis by directly compressing the placental bed. Uterine compression sutures stop uterine bleeding by external pressure on the uterus. Additionally, ligation of the uterine artery and internal iliac artery interrupts the flow of blood vessels to the uterus. Peripartum hysterectomy is performed when all of these other treatment options are exhausted [2].

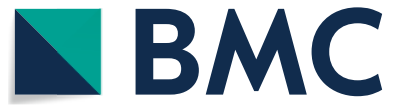

(c) The Author(s) 2021. Open Access This article is licensed under a Creative Commons Attribution 4.0 International License, which permits use, sharing, adaptation, distribution and reproduction in any medium or format, as long as you give appropriate credit to the original author(s) and the source, provide a link to the Creative Commons licence, and indicate if changes were made. The images or other third party material in this article are included in the article's Creative Commons licence unless indicated otherwise in a credit line to the material. If material is not included in the article's Creative Commons licence and your intended use is not permitted by statutory regulation or exceeds the permitted use, you will need to obtain permission directly from the copyright holder. To view a copy of this licence, visit http://creativecommons.org/licenses/by/4.0/. The Creative Commons Public Domain Dedication waiver (http://creativeco mmons.org/publicdomain/zero/1.0/) applies to the data made available in this article, unless otherwise stated in a credit line to the data. 
Uterine artery embolization (UAE) is frequently used as an alternative treatment to other interventions. The effectiveness of UAE is high and a recent review reported a $90 \%$ success rate [3]. However, UAE is not always successful, and various factors, including disseminated intravascular coagulation (DIC), have been associated with the failure of UAE [4]. We report the success of repeated UAE in a patient with PPH and DIC.

\section{Case presentation}

The patient was a 37-year-old primigravida who had no medical history. Her pregnancy was achieved using fertility treatment and she was carrying dichorionic diamniotic twins. She also had placenta previa. Both of the patient's fetuses were well developed, and their condition was good.

She underwent a cesarean section at 35 weeks of gestation because she complained of frequent uterine contractions and we were concerned about heavy genital bleeding. She delivered healthy male and female neonates (2426 g, Apgar score of 8 at $1 \mathrm{~min}$; and $2196 \mathrm{~g}$, Apgar score of 8 at $1 \mathrm{~min}$ ) through a transverse incision of the uterine body, to avoid making an incision in the low placenta. She experienced extensive intraoperative bleeding owing to uterine atony and placenta previa, with $4950 \mathrm{~mL}$ of blood loss. We inserted an intrauterine balloon tamponade device and sutured the uterine incision in two layers, with successful hemostasis. We transfused 6 units of red blood cells (RBCs) and 4 units of fresh frozen plasma (FFP) during surgery.

The patient's postoperative course is shown in Fig. 1. Postoperative blood tests showed a hemoglobin concentration of $4.5 \mathrm{~g} / \mathrm{dL}$, platelet count of $9.6 \times 10^{4} / \mu \mathrm{L}$, fibrinogen concentration of $130 \mathrm{mg} / \mathrm{dL}$, and fibrin degradation product (FDP) concentration of $44 \mu \mathrm{g} / \mathrm{mL}$. Her DIC score was 4 points according to the diagnostic criteria of the International Society for Thrombosis and Hemostasis (ISTH). Her systolic blood pressure was $123 \mathrm{mmHg}$ and her pulse rate was 90 beats/min. Her hemodynamics were stable, her uterus was contracting well, and there was no bleeding. We performed blood transfusions with 12 units of RBCs and 10 units of FFP.

However, she experienced further excessive bleeding $5 \mathrm{~h}$ after surgery and received $10 \mathrm{U}$ oxytocin, $0.2 \mathrm{mg}$ methyl ergometrine, and $1 \mathrm{~g}$ tranexamic acid intravenously. However, these treatments were ineffective,

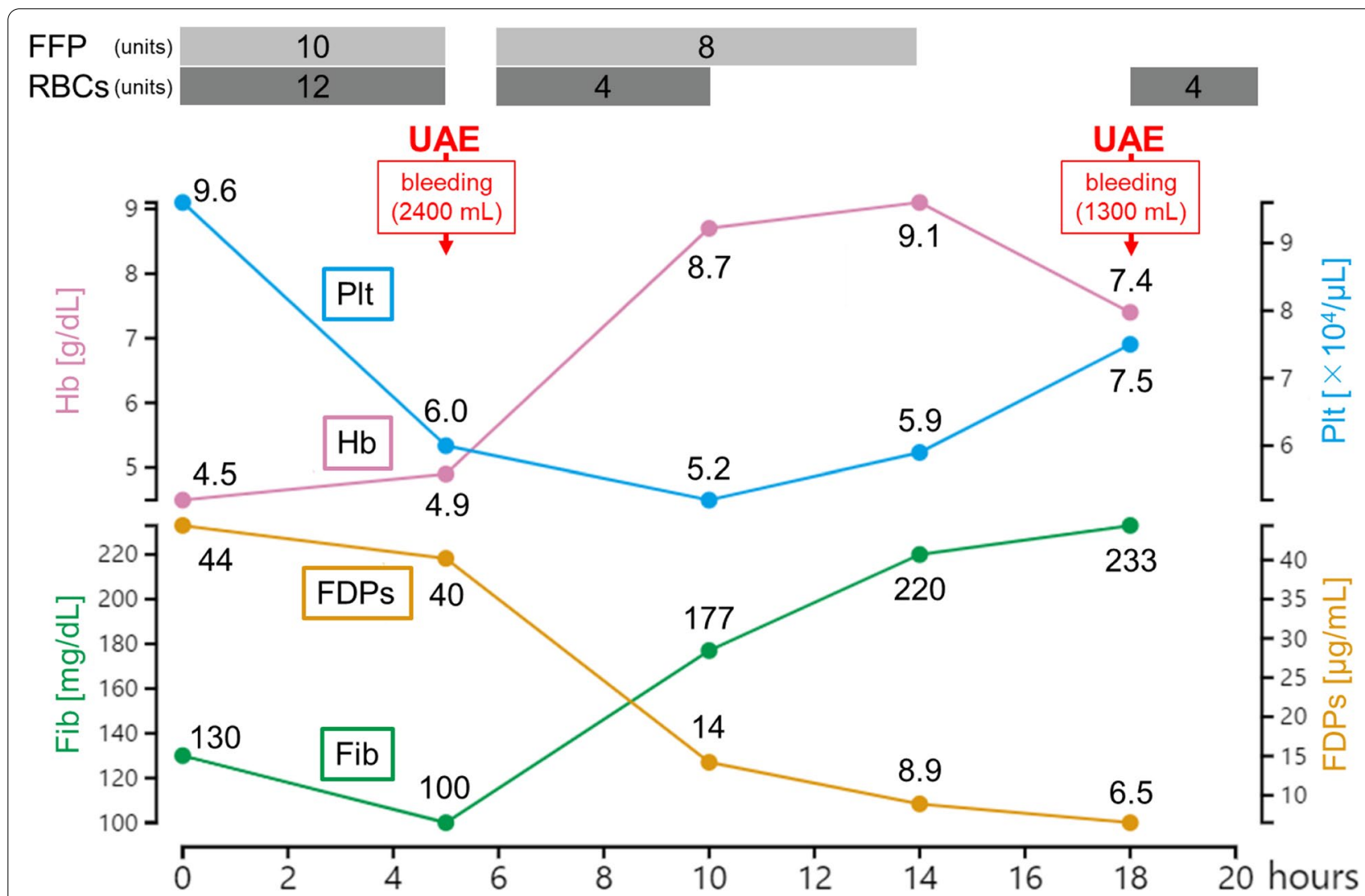

Fig. 1 The patient's postoperative course. FDPs: fibrin degradation products,FFP: fresh frozen plasma, Fib: fibrinogen, Hb: hemoglobin, Plt: platelets, RBCs:red blood cells, UAE: uterine artery embolization 

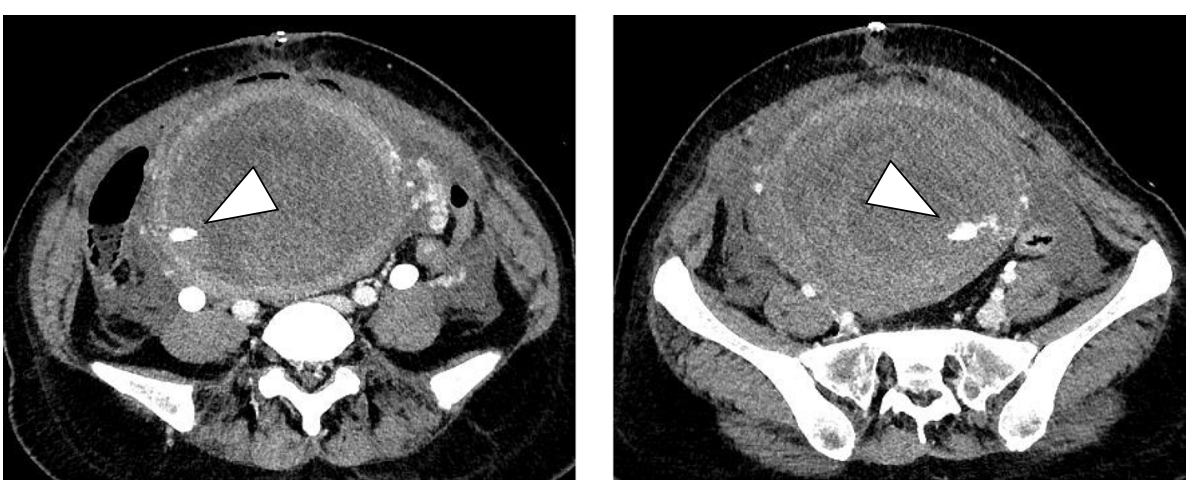

Fig. 2 Contrast-enhanced computed tomography images. A computed tomography scanperformed during the arterial phase shows extravasation from the bilateraluterus body (arrowheads)

and her blood loss was $2400 \mathrm{~mL}$. Blood tests showed a hemoglobin concentration of $4.9 \mathrm{~g} / \mathrm{dL}$, platelet count of $6.0 \times 10^{4} / \mu \mathrm{L}$, fibrinogen concentration of $100 \mathrm{mg} / \mathrm{dL}$, and FDP concentration of $40 \mu \mathrm{g} / \mathrm{mL}$. According to the ISTH diagnostic criteria, her DIC score was 5 points, which indicated overt DIC. We performed UAE and embolized both uterine arteries with gelatin sponges. Postembolization arteriography showed occlusion of both uterine arteries, and her bleeding subsided. We continued blood transfusions, and blood tests at 10 and $14 \mathrm{~h}$ after surgery showed an improvement in DIC.

However, the patient experienced further excessive bleeding $18 \mathrm{~h}$ after surgery. Dynamic computed tomography was performed to identify the source of bleeding, and extravasation from both uterine arteries to the lumen of the uterus was observed in the arterial phase (Fig. 2). There were no findings indicating retroperitoneal hematoma or uterine rupture. Her blood loss was $1300 \mathrm{~mL}$. Blood tests showed a hemoglobin concentration of $7.4 \mathrm{~g} / \mathrm{dL}$, platelet count of $7.5 \times 10^{4} / \mu \mathrm{L}$, fibrinogen concentration of $233 \mathrm{mg} / \mathrm{dL}$, and FDP concentration of $6.5 \mu \mathrm{g} / \mathrm{mL}$, and her DIC score was 1 point. Her DIC was treated successfully by blood transfusions. Her hemodynamics were stable.

We decided to perform repeated UAE. The uterine arteries on both sides were completely recanalized. We found extravasation only in the left uterine artery. We re-embolized both uterine arteries with gelatin
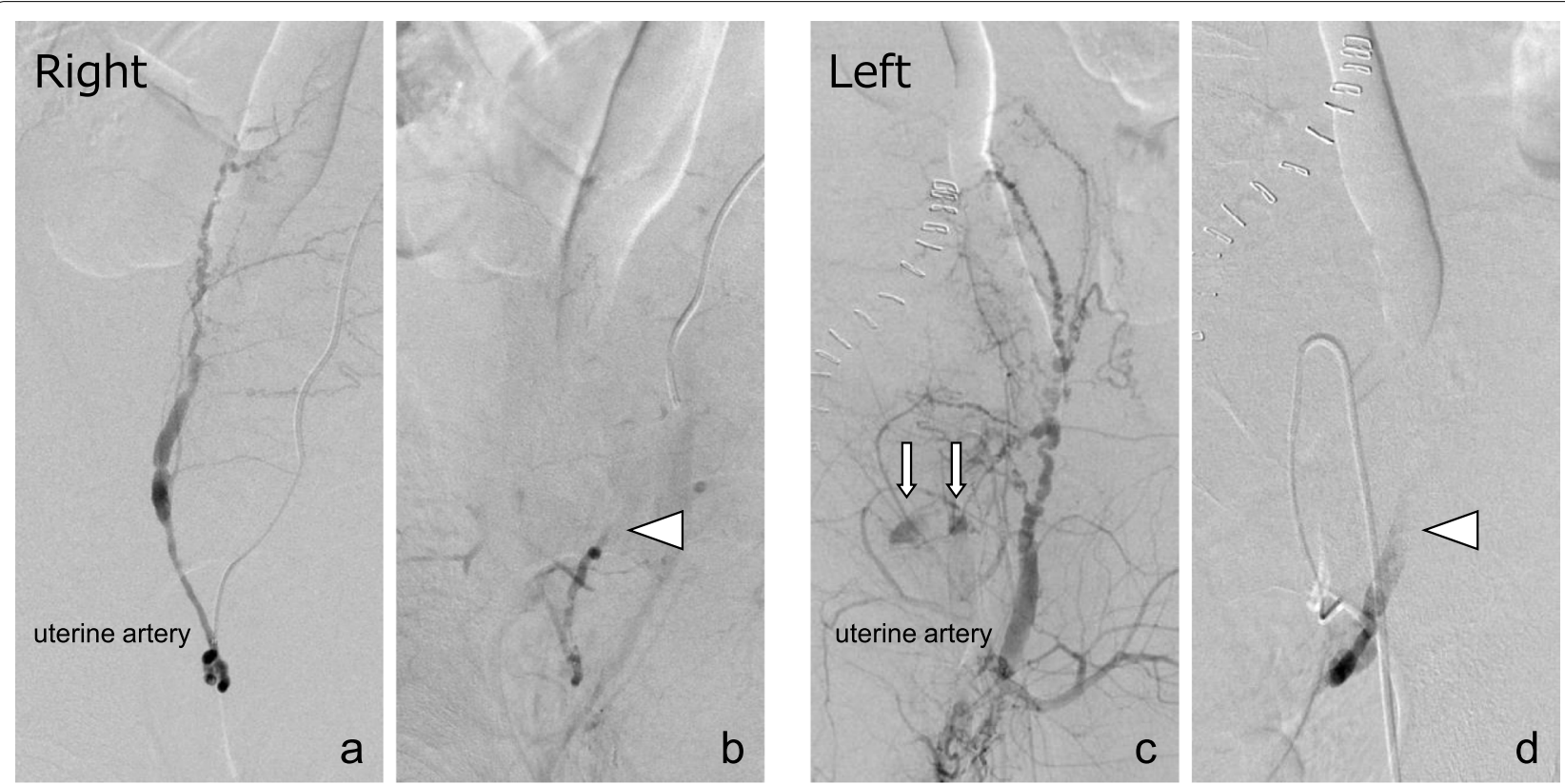

Fig. 3 Arteriography before and after uterine artery embolization. a The right uterineartery was completely recanalized. b The right uterine artery was completelyembolized using a gelatin sponge (arrowhead). c The left uterine artery wascompletely recanalized and showed extravasation (arrow). $\mathbf{d}$ The left uterineartery was completely embolized using a gelatin sponge (arrowhead) 
Table 1 Summary of risk factors associated with uterine artery embolization failure in patients with postpartum hemorrhage

\begin{tabular}{|c|c|c|c|c|c|c|c|}
\hline No & $\begin{array}{l}\text { First } \\
\text { author }\end{array}$ & $\begin{array}{l}\text { Year } \\
\text { published }\end{array}$ & No. of cases & Success & Failure & Risk factors by univariate analysis & Notes \\
\hline 1 & Shim [5] & 2006 & 49 & $42(86 \%)$ & $7(14 \%)$ & (1) abnormal placentation & No multivariate analysis. \\
\hline 2 & Touboul [6] & 2008 & 102 & $59(58 \%)$ & $43(42 \%)$ & $\begin{array}{l}\text { (1) cesarean section, (2) hemody- } \\
\text { namic shock }\end{array}$ & $\begin{array}{l}\text { These two factors were significant in } \\
\text { multivariate analysis. }\end{array}$ \\
\hline 3 & Kirby [7] & 2009 & 43 & $34(79 \%)$ & $9(21 \%)$ & (1) the existent of extravasation & No multivariate analysis. \\
\hline 4 & Sentilhes [8] & 2009 & 100 & $89(89 \%)$ & $11(11 \%)$ & $\begin{array}{l}\text { (1) blood loss }>1500 \mathrm{ml} \text {, (2) transfu- } \\
\text { sion }>5 \text { RBC units }\end{array}$ & No multivariate analysis. \\
\hline 5 & Ganguli [9] & 2011 & 66 & $63(95 \%)$ & $3(5 \%)$ & (1) transfusion requirement after UAE & No multivariate analysis. \\
\hline 6 & Bros [10] & 2012 & 148 & $136(92 \%)$ & $12(8 \%)$ & $\begin{array}{l}\text { (1) primiparity, (2) coagulation } \\
\text { disorders } \\
\text { (3) anatomic variant of the uterine } \\
\text { arterial vasculature }\end{array}$ & $\begin{array}{l}\text { These three factors were significant in } \\
\text { multivariate analysis. }\end{array}$ \\
\hline 7 & Lee [11] & 2012 & 251 & $217(86 \%)$ & $34(14 \%)$ & $\begin{array}{l}\text { (1) cesarean section, (2) DIC, (3) trans- } \\
\text { fusion }>10 \text { RBC units }\end{array}$ & $\begin{array}{l}\text { (2) and (3) were significant in multivari- } \\
\text { ate analysis. }\end{array}$ \\
\hline 8 & Poujade [12] & 2012 & 98 & $90(92 \%)$ & $8(8 \%)$ & $\begin{array}{l}\text { (1) placenta accreta spectrum, (2) } \\
\text { biologic factor (hemoglobin level, } \\
\text { prothrombin time, fibrinogen level), } \\
\text { (3) transfusional factor (RBC and FFP } \\
\text { transfusion, the number of packed } \\
\text { RBC units) }\end{array}$ & No multivariate analysis. \\
\hline 9 & Kim [4] & 2013 & 257 & $233(91 \%)$ & $24(9 \%)$ & $\begin{array}{l}\text { (1) hemodynamic instability, (2) } \\
\text { hemoglobin level }<8 \mathrm{~g} / \mathrm{dL} \\
\text { (3) DIC, (4) the existent of extravasa- } \\
\text { tion }\end{array}$ & $\begin{array}{l}\text { Only DIC was significant in multivariate } \\
\text { analysis. }\end{array}$ \\
\hline 10 & Cheong [13] & 2014 & 117 & $103(88 \%)$ & $14(12 \%)$ & $\begin{array}{l}\text { (1) DIC, (2) transfusion > } 10 \mathrm{RBC} \text { units } \\
\text { (3) embolization both uterine and } \\
\text { ovarian arteries }\end{array}$ & $\begin{array}{l}\text { (2) and (3) were significant in multivari- } \\
\text { ate analysis. }\end{array}$ \\
\hline 11 & Zhang [14] & 2015 & 68 & $53(78 \%)$ & $15(22 \%)$ & $\begin{array}{l}\text { (1) hemodynamic instability, (2) } \\
\text { hemoglobin level }<9.5 \mathrm{~g} / \mathrm{dL} \\
\text { (3) DIC }\end{array}$ & No multivariate analysis. \\
\hline 12 & Tanahashi [15] & 2017 & 57 & $43(75 \%)$ & $14(25 \%)$ & $\begin{array}{l}\text { (1) uterine height, (2) systolic blood } \\
\text { pressure } \\
\text { (3) hemoglobin level }\end{array}$ & $\begin{array}{l}\text { (1) and (2) were significant in multivari- } \\
\text { ate analysis. }\end{array}$ \\
\hline 13 & Lai [16] & 2017 & 33 & $24(73 \%)$ & $9(27 \%)$ & $\begin{array}{l}\text { (1) maternal age, (2) blood loss, (3) } \\
\text { platelet count } \\
\text { (4) history of miscarriage }\end{array}$ & $\begin{array}{l}\text { (1) and (3) were significant in multivari- } \\
\text { ate analysis. }\end{array}$ \\
\hline 14 & Aoki [17] & 2018 & 33 & $28(85 \%)$ & $5(15 \%)$ & $\begin{array}{l}\text { (1) retained placental tissue, (2) type } \\
\text { of ovarian artery } \\
\text { (3) the existent of extravasation }\end{array}$ & No multivariate analysis. \\
\hline 15 & Ueshima [18] & 2018 & 63 & $45(71 \%)$ & $18(29 \%)$ & $\begin{array}{l}\text { (1) uterine arteriography classifica- } \\
\text { tion, (2) placenta disorders }\end{array}$ & $\begin{array}{l}\text { Only uterine arteriography classifica- } \\
\text { tion was significant in multivariate } \\
\text { analysis. }\end{array}$ \\
\hline
\end{tabular}

sponges, and postembolization arteriography showed occlusion of both uterine arteries (Fig. 3). No further bleeding was observed.

The total estimated blood loss throughout the process was approximately $9000 \mathrm{~mL}$. The patient received 26 units of RBCs and 22 units of FFP. The patient's condition after UAE was good and she was discharged on the 7 th day postoperatively.

\section{Discussion and conclusion}

$\mathrm{UAE}$ is the preferred treatment for refractory $\mathrm{PPH}$ because of its high efficacy and safety, low invasiveness, and preservation of fertility. The success rate of temporary hemostasis is reported to be $99 \%$, and the success rate with no additional treatment is 90\% [3]. However, while UAE is usually highly effective, it can fail. Little is known about the risk factors associated with the failure of UAE.

We reviewed the factors associated with the failure of UAE. We identified articles in PubMed using the following search string: (Uterine Artery Embolization[MeSH] OR pelvic-embo* OR artery-embo* OR arterial-embo*) AND (postpartum hemorrhage[MeSH]). All included articles were peer reviewed, were published in English from 1 to 2000 to 31 August 2021, and also included relevant articles identified by manual searching. We 


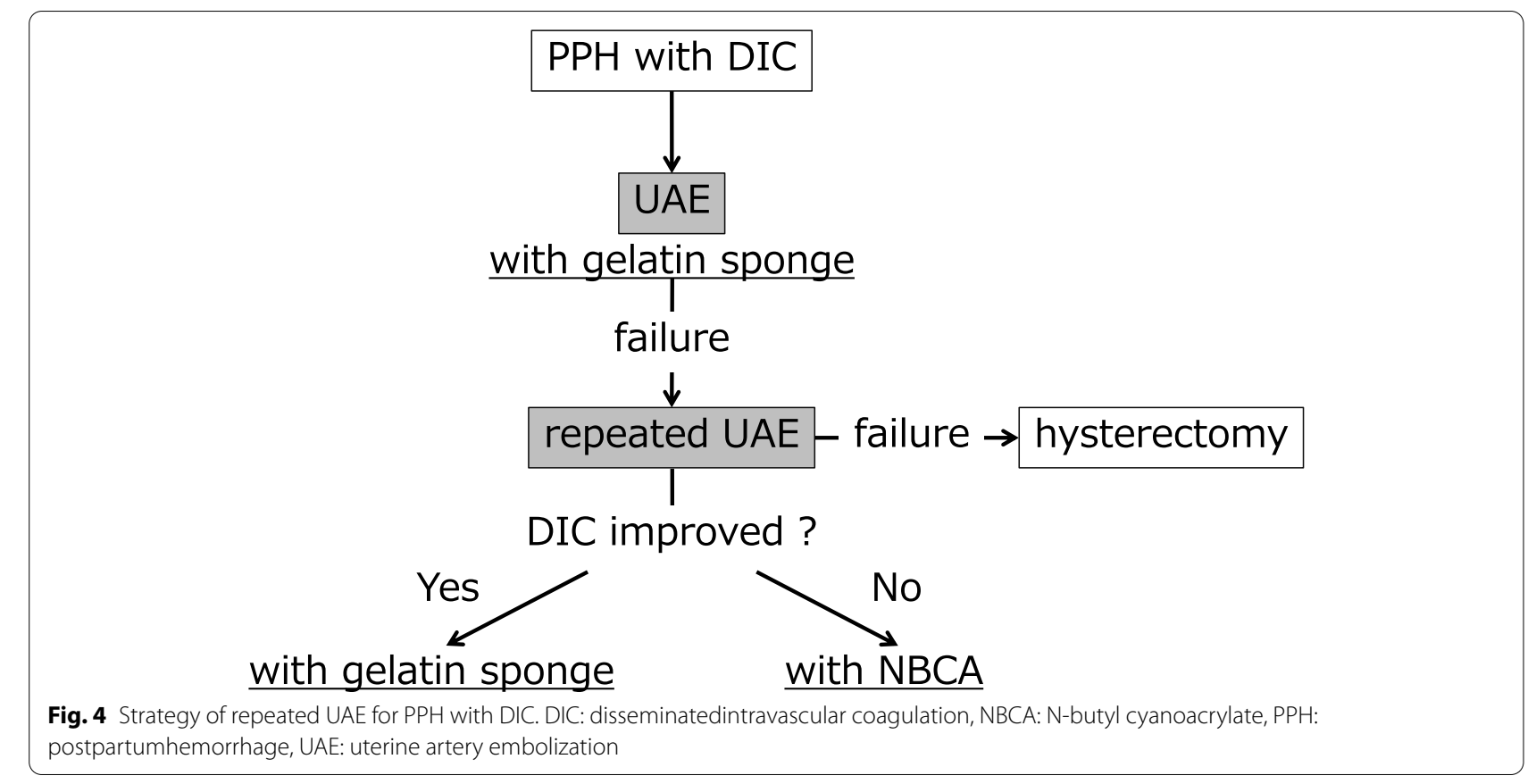

extracted information on factors associated with the failure of UAE from the manuscripts. We excluded studies where the definition of success or failure was ambiguous and no significant difference was found in any factors. The 15 included articles are shown in Table 1 [4-18].

Kim et al's study [4] included the largest number of cases and identified DIC as an independent failure factor for UAE. Other studies also reported that DIC and coagulation disorders were risk factors for the failure of UAE [10-14]. However, the definitions of DIC differed among these reports. Kim et al., Cheong et al., and Zhang et al. $[4,13,14]$ used the ISTH definition of DIC, while Lee et al. [11] described the diagnostic criteria in their report, and Bros et al. [10] did not define coagulation disorders. To use DIC as a clinically useful factor, it should be defined according to the ISTH criteria, rather than using a vague term such as coagulation disorders.

In the current case, we used the ISTH definition of 5 points for the first UAE and 1 point for repeated UAE, which indicated an improvement in DIC. We consider that this improvement in DIC led to the success of repeated UAE.

Some studies $[4,8,9,11-16]$ have suggested that estimated blood loss, hemoglobin concentrations, and total blood transfusion volume might be associated with the failure of UAE. The amount of blood loss during the perinatal period may be underestimated [19]. Additionally, the volumes of blood loss and blood transfused are based on the final state of the patient, and are not useful for predicting the failure of UAE. We believe that DIC results in an increase in blood loss and blood transfused. DIC is easily diagnosed using tests and may be a useful clinical predictor of UAE failure. Hemodynamic instability has also been reported as a factor for the failure of UAE [4, $6,14]$. Therefore, hemodynamic stabilization and treatment of DIC using adequate fluids, RBCs, FFP, and platelet transfusions are important to increase the success rate of UAE.

A limitation of this review is that each study had a different success rate. There are some important differences between the studies, including the cause and severity of $\mathrm{PPH}$, and the presence or absence of DIC. A multicenter prospective study with a larger sample size with unified conditions is required to further clarify the factors associated with the failure of UAE.

We considered the possible reasons for the low success rate of UAE for PPH with DIC. Gelatin sponges are generally the preferred embolic material. A gelatin sponge is absorbed within approximately $2-6$ weeks and is thus classified as a temporary embolic material. A gelatin sponge achieves vascular occlusion by filling the blood vessel, resulting in physical stagnation of blood flow and the formation of a thrombus around the sponge [20]. Therefore, the ability of the gelatin sponge to cause an embolism depends on the patient's coagulation ability, suggesting that the material is more likely to fail when used in patients with DIC. 
DIC is a common complication of $\mathrm{PPH}$, and untreated DIC can lead to further massive uncontrolled bleeding. Successful UAE in patients with DIC requires their DIC to be corrected first, or an embolic material that does not depend on the patient's coagulation ability, such as N-butyl cyanoacrylate (NBCA), needs to be used. NBCA achieves embolization by entering the vessel and polymerizing with cations, thereby occluding the vessel lumen [3]. Unlike a gelatin sponge, NBCA is a permanent embolization material.

Several studies have reported that NBCA for PPH with DIC is effective [21-23]. However, the number of these reports is limited. Complications, including the effect of NBCA on future pregnancies, are also unclear. Additionally, this technique requires specific skills. Therefore, we consider that the use of NBCA should be restricted until further evidence is provided.

In a recent review, prior UAE was associated with $\mathrm{PPH}$ and the placenta previa spectrum during the next pregnancy [24]. UAE may reduce blood flow to the uterus and damage the endometrium. Additionally, repeated UAE may be associated with higher complication rates because the use of a large volume of embolic agents blocks blood flow in the uterus and damages it [24].

We propose the strategy of repeated UAE for PPH with DIC (Fig. 4). UAE using a gelatin sponge is initially applied. If further bleeding occurs, repeated UAE using a gelatin sponge will probably achieve hemostasis if the DIC has improved, as in the current case. However, NBCA may be considered if the patient's DIC has not improved. A recent review showed that UAE was beneficial for reducing blood loss and the operation time compared with peripartum hysterectomy, and it had a comparable hemostatic efficacy rate [25]. We recommend using repeated UAE before hysterectomy.

In conclusion, the success rate of UAE is reduced in patients with $\mathrm{PPH}$ with DIC, and requires careful consideration. Repeated UAE is an effective procedure and should help to avoid a hysterectomy.

\section{Abbreviations}

DIC: disseminated intravascular coagulation; FDP: fibrin degradation product; FFP: fresh frozen plasma; ISTH: International Society for Thrombosis and Hemostasis; NBCA: N-butyl cyanoacrylate; PPH: postpartum hemorrhage; RBCs: red blood cells; UAE: uterine artery embolization.

\section{Acknowledgements}

We thank Susan Furness, PhD, from Edanz (https://jp.edanz.com/ac) for editing a draft of this manuscript.

\section{Authors' contributions}

SS collected the data, performed data analysis, wrote the manuscript, and edited the manuscript. TN collected the data, performed formal analysis, and revised the manuscript. KT, TS and KH collected the data and revised the manuscript. TE and KN revised the manuscript. All authors read and approved the manuscript.
Funding

None.

Availability of data and materials

All data related to this report are available from the corresponding author on reasonable request.

\section{Declarations}

Ethics approval and consent to participate

Not applicable.

\section{Consent for publication}

Written informed consent was obtained from the patient for publication of this case report and accompanying images.

\section{Competing interests}

The authors declare that they have no competing interests.

\section{Author details}

'Departments of Obstetrics and Gynecology, Niigata University Medical and Dental Hospital, 1-757 Asahimachi-dori, Chuo-ku, 951-8510 Niigata, Japan. ${ }^{2}$ Radiology and Radiation Oncology, Niigata University Medical and Dental Hospital, Niigata, Japan.

Received: 30 July 2021 Accepted: 12 October 2021

Published online: 22 October 2021

\section{References}

1. Neary C, Naheed S, McLernon DJ, Black M. Predicting risk of postpartum haemorrhage: a systematic review. BJOG. 2021;128(1):46-53.

2. Kellie FJ, Wandabwa JN, Mousa HA, Weeks AD. Mechanical and surgical interventions for treating primary postpartum haemorrhage. Cochrane Database Syst Rev. 2020;7(7):CD013663.

3. Zhang XQ, Chen XT, Zhang YT, Mai CX. The Emergent Pelvic Artery Embolization in the Management of Postpartum Hemorrhage: A Systematic Review and Meta-analysis. Obstet Gynecol Surv. 2021;76(4):234-44.

4. Kim YJ, Yoon CJ, Seong NJ, Kang SG, An SW, Kim YS, et al. Failed pelvic arterial embolization for postpartum hemorrhage: clinical outcomes and predictive factors. J Vasc Interv Radiol. 2013;24(5):703-9.

5. Shim JY, Yoon HK, Won HS, Kim SK, Lee PR, Kim A. Angiographic embolization for obstetrical hemorrhage: effectiveness and follow-up outcome of fertility. Acta Obstet Gynecol Scand. 2006;85(7):815-20.

6. Touboul C, Badiou W, Saada J, Pelage JP, Payen D, Vicaut E, et al. Efficacy of selective arterial embolisation for the treatment of lifethreatening post-partum haemorrhage in a large population. PLoS One. 2008;3(11):e3819.

7. Kirby JM, Kachura JR, Rajan DK, Sniderman KW, Simons ME, Windrim RC, et al. Arterial embolization for primary postpartum hemorrhage. J Vasc Interv Radiol. 2009;20(8):1036-45.

8. Sentilhes L, Gromez A, Clavier E, Resch B, Verspyck E, Marpeau L. Predictors of failed pelvic arterial embolization for severe postpartum hemorrhage. Obstet Gynecol. 2009;113(5):992-9.

9. Ganguli S, Stecker MS, Pyne D, Baum RA, Fan CM. Uterine artery embolization in the treatment of postpartum uterine hemorrhage. J Vasc Interv Radiol. 2011;22(2):169-76.

10. Bros S, Chabrot P, Kastler A, Ouchchane L, Cassagnes L, Gallot D, et al. Recurrent bleeding within 24 hours after uterine artery embolization for severe postpartum hemorrhage: are there predictive factors? Cardiovasc Intervent Radiol. 2012:35(3):508-14.

11. Lee HY, Shin JH, Kim J, Yoon HK, Ko GY, Won HS, et al. Primary postpartum hemorrhage: outcome of pelvic arterial embolization in 251 patients at a single institution. Radiology. 2012;264(3):903-9.

12. Poujade O, Zappa M, Letendre I, Ceccaldi PF, Vilgrain V, Luton D. Predictive factors for failure of pelvic arterial embolization for postpartum hemorrhage. Int J Gynaecol Obstet. 2012;117(2):119-23. 
13. Cheong JY, Kong TW, Son JH, Won JH, Yang Jl, Kim HS. Outcome of pelvic arterial embolization for postpartum hemorrhage: A retrospective review of 117 cases. Obstet Gynecol Sci. 2014;57(1):17-27.

14. Zhang E, Liu L, Owen R. Pelvic Artery Embolization in the Management of Obstetrical Hemorrhage: Predictive Factors for Clinical Outcomes. Cardiovasc Intervent Radiol. 2015;38(6):1477-86.

15. Tanahashi Y, Goshima S, Kondo H, Ando T, Noda Y, Kawada H, et al. Transcatheter Arterial Embolization for Primary Postpartum Hemorrhage: Predictive Factors of Need for Embolic Material Conversion of Gelatin Sponge Particles to N-Butyl Cyanoacrylate. Cardiovasc Intervent Radiol. 2017:40(2):236-44.

16. Lai BM, Shum JS, Chu CY, Lo SS, Lau KY. Predictors of the success and failure of emergency pelvic artery embolisation for primary postpartum haemorrhage: a 12-year review. Singapore Med J. 2017;58(5):272-8.

17. Aoki M, Tokue H, Miyazaki M, Shibuya K, Hirasawa S, Oshima K. Primary postpartum hemorrhage: outcome of uterine artery embolization. Br J Radiol. 2018;91(1087):20180132.

18. Ueshima E, Sugimoto K, Okada T, Katayama N, Koide Y, Sofue K, et al. Classification of uterine artery angiographic images: a predictive factor of failure in uterine artery embolization for postpartum hemorrhage. Jpn J Radiol. 2018;36(6):394-400.

19. Spreu A, Abgottspon F, Baumann MU, Kettenbach J, Surbek D. Efficacy of pelvic artery embolisation for severe postpartum hemorrhage. Arch Gynecol Obstet. 2017;296(6):1117-24.

20. Loffroy R, Guiu B, Cercueil JP, Krausé D. Endovascular therapeutic embolisation: an overview of occluding agents and their effects on embolised tissues. Curr Vasc Pharmacol. 2009;7(2):250-63.
21. Obata S, Kasai M, Kasai J, Seki K, Sekikawa Z, Torimoto I, et al. Emergent Uterine Arterial Embolization Using N-Butyl Cyanoacrylate in Postpartum Hemorrhage with Disseminated Intravascular Coagulation. Biomed Res Int. 2017;2017:1562432.

22. Igarashi S, Izuchi S, Ogawa Y, Yoshimathu M, Takizawa K, Nakajima Y, et al. $\mathrm{N}$-butyl cyanoacrylate is very effective for massive haemorrhage during the perinatal period. PLoS One. 2013;8(10):e77494.

23. Kanematsu M, Watanabe H, Kondo H, Goshima S, Kato H, Furui T, et al. Postpartum hemorrhage in coagulopathic patients: preliminary experience with uterine arterial embolization with N-butyl cyanoacrylate. J Vasc Interv Radiol. 2011;22(12):1773-6.

24. Matsuzaki S, Lee M, Nagase Y, Jitsumori M, Matsuzaki S, Maeda M, et al. A systematic review and meta-analysis of obstetric and maternal outcomes after prior uterine artery embolization. Sci Rep. 2021;11(1):16914.

25. Liu Z, Wang Y, Yan J, Li J, Liu X, Zhang L, et al. Uterine artery embolization versus hysterectomy in the treatment of refractory postpartum hemorrhage: a systematic review and meta-analysis. J Matern Fetal Neonatal Med. 2020;33(4):693-705.

\section{Publisher's Note}

Springer Nature remains neutral with regard to jurisdictional claims in published maps and institutional affiliations.
Ready to submit your research? Choose BMC and benefit from:

- fast, convenient online submission

- thorough peer review by experienced researchers in your field

- rapid publication on acceptance

- support for research data, including large and complex data types

- gold Open Access which fosters wider collaboration and increased citations

- maximum visibility for your research: over $100 \mathrm{M}$ website views per year

At BMC, research is always in progress.

Learn more biomedcentral.com/submissions 